\title{
Environmental exposure to pesticides and respiratory health
}

\author{
Ali Mamane ${ }^{1,2}$, Chantal Raherison ${ }^{1,2,3}$, Jean-François Tessier², \\ Isabelle Baldi ${ }^{1,2,4}$ and Ghislaine Bouvier ${ }^{1,2}$
}

\begin{abstract}
Affiliations: ${ }^{1}$ ISPED - Laboratoire Santé Travail Environnement, Université de Bordeaux, Bordeaux, France. ${ }^{2}$ ISPED - Centre INSERM U897-Epidémiologie-Biostatistique, Bordeaux, France. ${ }^{3}$ Service des Maladies Respiratoire, CHU de Bordeaux, Bordeaux, France. ${ }^{4}$ Service de Médecine du Travail, CHU de Bordeaux, Bordeaux, France.
\end{abstract}

Correspondence: Ali Mamane, Université de Bordeaux, ISPED, INSERM U897, 146 rue Leo Saignat, Bordeaux, 33076, France. E-mail: ali.mamanedisped.u-bordeaux2.fr

ABSTRACT Respiratory effects of environmental exposure to pesticides are debated. Here we aimed to review epidemiological studies published up until 2013, using the PubMed database. 20 studies dealing with respiratory health and non-occupational pesticide exposure were identified, 14 carried out on children and six on adults.

In four out of nine studies in children with biological measurements, mothers' dichlorodiphenyldichloroethylene (DDE) blood levels during pregnancy were associated with asthma and wheezing in young children. An association was also found between permethrin in indoor air during pregnancy and wheezing in children. A significant association between asthma and DDE measured in children's blood (aged 7-10 years) was observed in one study. However, in three studies, no association was found between asthma or respiratory infections in children and pesticide levels in breast milk and/or infant blood. Lastly, in three out of four studies where post-natal pesticide exposure of children was assessed by parental questionnaire an association with respiratory symptoms was found. Results of the fewer studies on pesticide environmental exposure and respiratory health of adults were much less conclusive: indeed, the associations observed were weak and often not significant.

In conclusion, further studies are needed to confirm whether there is a respiratory risk associated with environmental exposure to pesticides.

@ERSpublications

Occupational pesticide exposure increases respiratory health risk but data are unclear for environmental exposures http://ow.ly/PSGvz

\section{Introduction}

According to the World Health Organization, chronic respiratory diseases, including asthma and chronic obstructive pulmonary disease (COPD), were the leading cause of total world morbidity (6.2\%) and the third leading cause of all global deaths (7.1\%) in 2008 [1]. Asthma is the most common chronic disease, affecting $\sim 14 \%$ of children in the world, and its prevalence has been increasing for several decades [2]. In addition, respiratory diseases are the most common causes of death among children under 5 years of age [3]. It is now accepted that, besides viruses and bacteria, environmental agents can induce or exacerbate airway inflammation, which can be a predictor of chronic respiratory diseases $[4,5]$. Some environmental risk factors are now well known, such as allergens, tobacco smoke, gaseous or particulate air pollutants, and exposure to certain chemicals, such as pesticides [6-8].

Received: July 302014 | Accepted after revision: Nov 302014

Conflict of interest: Disclosures can be found alongside the online version of this article at err.ersjournals.com

Provenance: Submitted article, peer reviewed.

Copyright CERS 2015. ERR articles are open access and distributed under the terms of the Creative Commons Attribution Non-Commercial Licence 4.0. 
The term pesticides commonly refers to chemical substances mainly used to control crop pests, i.e. insects (insecticides), microbiological diseases (fungicides) and "weeds" (herbicides). They are widely used in agriculture on crops and on cattle, but also in many other occupations and industries (gardening, floristry, veterinary medicine, community health, wood, textile and building material protection, etc.), as well as for domestic purposes at home and in the garden [9].

The general population is exposed through pesticide residues present in food, water, and the general and personal environment (indoor and outdoor air, soil, house dust, surfaces, etc.). Residential exposure depends on proximity of the house to areas treated with pesticides, the persistence of ancient pesticides used in or around the home, and domestic uses at home, in the garden, on pets (flies and ticks) and also on humans (lice and scabies) [10-12].

Pesticides are semi-volatile, even nonvolatile substances, and surface deposition occurs rapidly after use. These substances enter the body through the skin, and the digestive and respiratory tracts. The importance of these different pathways may differ regarding the type of exposure, the formulation used (e.g. sprays, wettable powders, diffusive devices or solid forms), the location of use (indoor or outdoor), and many other factors. Occupational exposure in agriculture occurs mainly via the dermal route, whereas the dietary oral route is considered to be the most important route of exposure for the general population $[13,14]$. However, non-dietary and respiratory routes may also be important ways of exposure, especially for children [12]. Children may also have come into contact with pesticides by transplacental passage and via breast milk contamination, notably with persistent bioaccumulative pesticides. In addition, levels of exposure of workers handling pesticides or working with treated crops or in treated environments are usually considered to be higher than levels of exposure for the general population. Thus, these qualitative, quantitative and temporal differences in exposure prevent us from predicting health effects in the general population based on those observed in occupational settings.

Recently, HeRnÁNDEZ et al. [15] have drawn attention to experimental studies suggesting a potential relationship between induced airway hyperreactivity in allergic asthma and pesticide exposure. ProsKocIL et al. [16] have reported a lower potentiated vagally induced bronchoconstriction threshold in allergen sensitised guinea pigs, and increased production of proinflammatory cytokines in guinea pigs induced by organophosphate insecticides [17]. FukUYAMA et al. [18] have also demonstrated, in BALBc mice, that the allergic potential of environmental chemical allergens could be increased by prior exposure to organophosphate and organochlorine insecticides. According to the authors, this can be explained by an increase of T-cell surface antigen expression.

If the respiratory consequences of pesticide exposure for workers are increasingly well documented, it is not the case for the general population living near treated fields or exposed by domestic use of pesticides. In particular, the pesticide exposure of farmers' families, especially children, can be potentially significant, with a combination of para-occupational, environmental and domestic exposures [19, 20]. Indeed, data from pilot studies carried out for the Agricultural Health Study in North Carolina and Iowa indicate high levels of pesticides in the homes of farming families and their children [21]. Subjects can also be exposed during public health campaigns where insecticides are applied, particularly for mosquito and cockroach control operations.

In this literature review, we summarise the study characteristics and main results of epidemiological studies dealing with domestic and environmental exposure to pesticides and the occurrence of respiratory diseases.

\section{Methods}

Our research was based on the recommendations of the PRISMA (preferred reporting items for systematic reviews and meta-analyses) statement for systematic reviews and meta-analyses [22]. A comprehensive search of published studies on occupational, domestic or environmental exposure to pesticides linked to respiratory health, including chronic diseases (including diagnoses of asthma and COPD) and clinical symptoms (coughing, dyspnoea, wheezing, asthma attacks, etc.) as well as impairment in respiratory function, was conducted using the MEDLINE database of the US National Library of Medicine (accessed via PubMed). An algorithm of the following keywords was used: "(pesticides OR agrochemicals OR insecticides OR fungicides OR herbicides) and (respiratory disorders OR respiratory diseases OR lung diseases OR wheeze OR asthma OR cough OR bronchitis OR dyspnea) and (epidemiology OR epidemiologic study OR case-control OR cohort) not warfarin." The limits "Humans" and "English/ French" language were applied to this literature search. The search was limited to studies until December 2013.

With this strategy, we identified a total of 427 items (fig. 1). The first selection of articles was performed upon reading titles and abstracts. Review articles that did not contain original data $(n=64)$ were excluded. Reading the abstracts of the 363 remaining articles ruled out 298 that were irrelevant to our review. Three articles from the authors' references were added to the 65 articles deemed relevant, giving a total of 68 


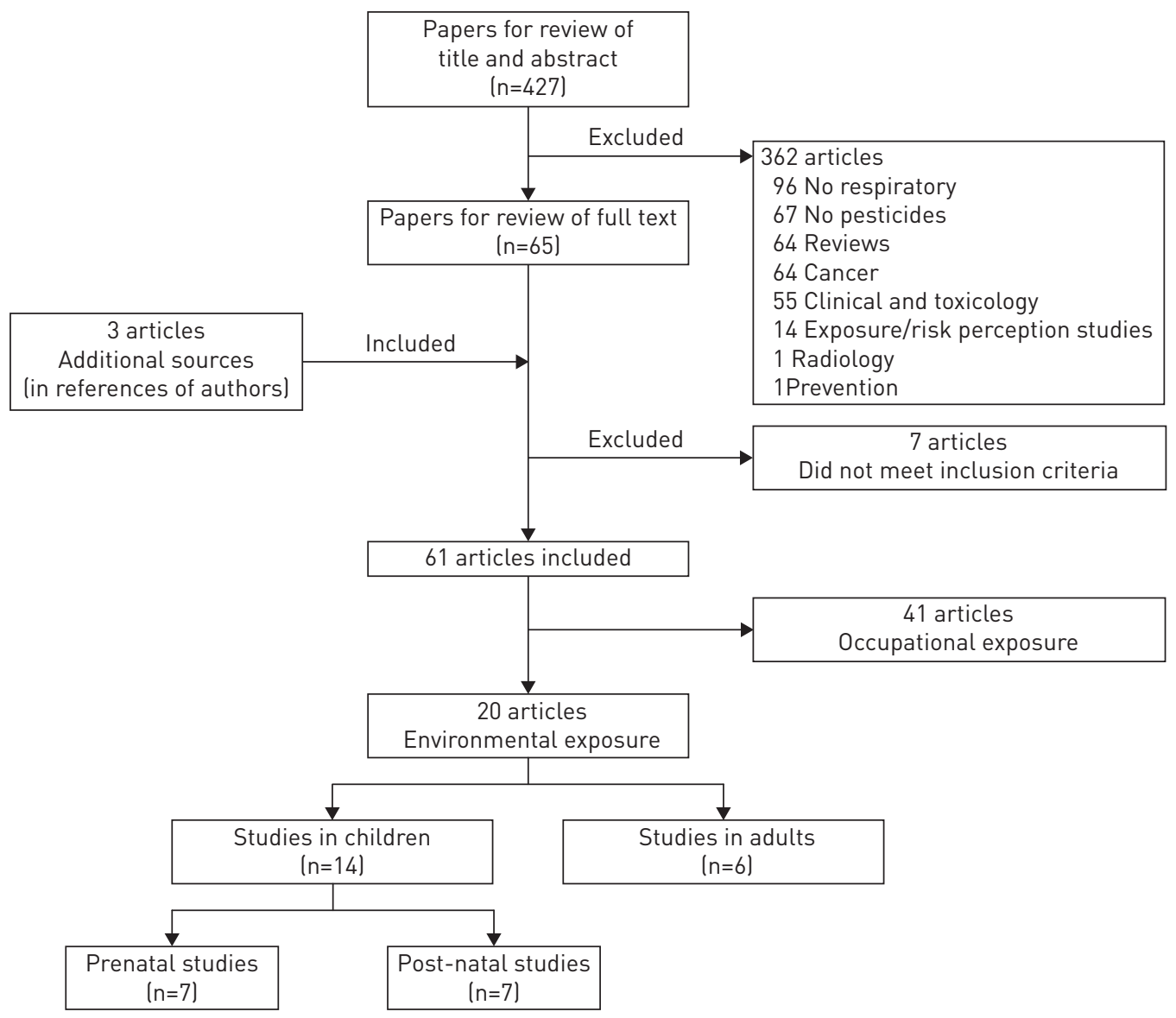

FIGURE 1 Flow chart of identification and selection of original articles finally included in the review of environmental exposure to pesticides and respiratory health.

articles. Reading the full text articles led to exclusion of another seven items: four did not specifically deal with respiratory diseases but instead with overall mortality [23-26], two studies were purely toxicological $[27,28]$ and the last one investigated cases of idiopathic pulmonary fibrosis with no notion about exposure to pesticides [29]. Thus, among the 61 articles finally selected, 41 dealt with occupational exposures and were summarised in another review, and 20 papers studied environmental exposures and are summarised in this review (fig. 1).

The following information was collected for each study using a standardised reading form: first author, year of publication, geographic location, type of study, objectives, type of population, type of respiratory effect, methods of exposure assessment, and the main results and conclusions.

Respiratory effects of environmental exposure to pesticides have been mainly studied in children. Fourteen studies on children have been identified by our research; seven assessed in utero pesticide exposure and seven assessed post-natal exposure to pesticides at different ages. In eight studies pesticide or metabolite measurements in biological fluids were performed, before birth in maternal blood $(n=3)$ or in cord blood $(n=2)$, and after birth in breast milk $(n=1)$ or in children's blood $(n=2)$. In other studies on children, exposure was assessed indirectly by questionnaires.

Six studies have examined the exposure of adults. One study assessed pesticide exposure by using biomarkers, three studies assessed household proximity to fields or spraying areas, in one study pesticide exposure was assessed by questionnaires, and in the last one exposure was documented without any precision.

\section{Studies in children}

In utero pesticide exposure

Studies of in utero pesticide exposure are summarised in table 1.

Four studies were conducted in Spain [30-33] to evaluate the association between prenatal exposure to organochlorine insecticides and the occurrence of childhood asthma. SunYer et al. [30] followed 482 
TABLE 1 Effects of pesticide exposure in children on respiratory health: prenatal exposure

\begin{tabular}{|c|c|c|c|c|c|c|c|}
\hline \multirow{2}{*}{$\begin{array}{l}\text { First author } \\
\text { [ref.] }\end{array}$} & \multirow[t]{2}{*}{ Location } & \multirow[t]{2}{*}{ Study design } & \multicolumn{4}{|c|}{ Summary of method } & \multirow[t]{2}{*}{ Results } \\
\hline & & & $\begin{array}{c}\text { Population } \\
\text { characteristics }\end{array}$ & Pesticides of interest & Exposure assessment & Health outcomes & \\
\hline SUNYER [30] & $\begin{array}{l}\text { Menorca, } \\
\text { Spain }\end{array}$ & Prospective cohort & $\begin{array}{l}468 \text { mother-infant } \\
\text { pairs, with complete } \\
\text { outcome data at } \\
4 \text { years }\end{array}$ & $\begin{array}{l}\text { Organochlorine } \\
\text { insecticides DDT and } \\
\text { its metabolite DDE } \\
\text { and fungicide HCB }\end{array}$ & $\begin{array}{l}\text { Cord serum: } \\
\text { DDE (median } 1.03 \mathrm{ng} \cdot \mathrm{mL}^{-1} \text { ); } \\
\text { HCB (median } 0.68 \mathrm{ng} \cdot \mathrm{mL}^{-1} \text { ) }\end{array}$ & $\begin{array}{l}\text { Face-to-face maternal } \\
\text { questionnaire: report of } \\
\text { persistent wheezing and/ } \\
\text { or doctor-diagnosed } \\
\text { asthma at } 4 \text { years of age }\end{array}$ & $\begin{array}{l}\text { Wheezing at } 4 \text { years of age } \\
\text { increased when DDE } \\
\text { concentration }>1.90 \mathrm{ng} \cdot \mathrm{mL}^{-1} \\
\text { (RR } 2.63,95 \% \mathrm{Cl} 1.19-4.69 \text { ) } \\
\text { and persistent wheezing } \\
\text { (RR 1.26, 95\% Cl 1.04-1.54) }\end{array}$ \\
\hline SUNYER [31] & $\begin{array}{l}\text { Menorca, } \\
\text { Spain }\end{array}$ & Prospective cohort & $\begin{array}{l}462 \text { mother-infant } \\
\text { pairs, with complete } \\
\text { outcome data at } \\
6.5 \text { years }\end{array}$ & $\begin{array}{c}\text { Organochlorines } \\
\text { DDE/DDT }\end{array}$ & $\begin{array}{l}\text { Cord serum: } \\
\text { DDE (median } 1.03 \mathrm{ng} \cdot \mathrm{mL}^{-1} \text { ); } \\
\text { DDT (median } 0.08 \mathrm{ng} \cdot \mathrm{mL}^{-1} \text { ) } \\
\text { Children's blood (at } 4 \text { years): } \\
\text { DDE (median } 0.08 \mathrm{ng} \cdot \mathrm{mL}^{-1} \text { ); } \\
\text { DDT (median } 0.05 \mathrm{ng} \cdot \mathrm{mL}^{-1} \text { ) }\end{array}$ & $\begin{array}{l}\text { Face-to-face maternal } \\
\text { questionnaire: report of } \\
\text { persistent wheezing and/ } \\
\text { or doctor-diagnosed } \\
\text { asthma at } 6.5 \text { years of age }\end{array}$ & $\begin{array}{l}\text { DDE concentration at birth } \\
\text { associated with diagnosis of } \\
\text { asthma at age } 6.5 \text { years } \\
\text { (OR } 1.18,95 \% \mathrm{Cl} 1.01-1.39 \text { ) } \\
\text { and wheeze at age } 4 \text { years } \\
\text { (OR } 1.14,95 \% \mathrm{Cl} 1.02-1.28 \text { ) }\end{array}$ \\
\hline SUNYER [32] & Spain & $\begin{array}{l}\text { Birth cohort of } \\
\text { Infancia y Medico } \\
\text { Ambiente (INMA) }\end{array}$ & $\begin{array}{l}520 \text { mother-infant } \\
\text { pairs, age: } \\
14 \text { months }\end{array}$ & $\mathrm{DDE}, \mathrm{HCH}$ & $\begin{array}{l}\text { Maternal serum (first trimester } \\
\text { of pregnancy): } \mathrm{pp}^{\prime} \mathrm{DDE} \\
\text { (mean } 112.3 \mathrm{ng} \cdot \mathrm{g}^{-1} \text { ); } \\
\text { HCB (mean } 43.7 \mathrm{ng} \cdot \mathrm{g}^{-1} \text { ) }\end{array}$ & $\begin{array}{l}\text { Face-to-face maternal } \\
\text { questionnaire to report } \\
\text { doctor-diagnosed LRTIs } \\
\text { including bronchitis, } \\
\text { bronchiolitis or } \\
\text { pneumonia }\end{array}$ & $\begin{array}{l}\text { Significant association of } \\
\text { DDE concentration during the } \\
\text { first trimester of pregnancy } \\
\text { with recurrent LRTI at } \\
6 \text { months (RR } 1.68,95 \% \mathrm{Cl} \\
0.06-2.66 \text { ), and } 14 \text { months } \\
\text { (RR } 1.52,95 \% \mathrm{Cl} 1.05-2.21 \text { ) }\end{array}$ \\
\hline GASCON [33] & Spain & $\begin{array}{l}\text { Birth cohort of } \\
\text { INMA }\end{array}$ & $\begin{array}{l}1455 \text { mother-infant } \\
\text { pairs, age: } \\
14 \text { months }\end{array}$ & $\mathrm{DDE}, \mathrm{HCH}$ & $\begin{array}{l}\text { Maternal serum (7-26th week of } \\
\left.\text { pregnancy): DDE (mean } 116.3 \mathrm{ng} \cdot \mathrm{g}^{-1}\right) \\
\text { HCB (mean } 46.4 \mathrm{ng} \cdot \mathrm{g}^{-1} \text { ) }\end{array}$ & $\begin{array}{l}\text { Face-to-face maternal } \\
\text { questionnaire to report } \\
\text { doctor-diagnosed of LRTIs } \\
\text { based on ISAAC } \\
\text { questionnaire }\end{array}$ & $\begin{array}{l}\text { DDE concentrations (third } \\
\text { quartile) associated with LRTI } \\
\text { risk (RR } 1.33,95 \% \mathrm{Cl} \\
\text { 1.08-1.62) and wheeze } \\
\text { (RR } 1.30,95 \% \mathrm{Cl} 1.06-1.59 \text { ) }\end{array}$ \\
\hline WeseLaK [34] & Canada & $\begin{array}{l}\text { Retrospective cohort } \\
\text { of Ontario Farm } \\
\text { Family Health Study } \\
\text { (OFFHS) }\end{array}$ & $\begin{array}{l}3405 \text { children of } \\
\text { farm families }\end{array}$ & $\begin{array}{l}\text { Agricultural } \\
\text { herbicides, } \\
\text { insecticides and } \\
\text { fungicides }\end{array}$ & $\begin{array}{l}\text { Questionnaire on pesticide exposure in } \\
\text { farm activities of the father and } \\
\text { mother during pregnancy, the year } \\
\text { and month of pesticide use being } \\
\text { matched with year and month of each } \\
\text { pregnancy } \\
\text { No pesticides measured }\end{array}$ & $\begin{array}{l}\text { Parental self-report of } \\
\text { doctor-diagnosed health } \\
\text { problems: chronic } \\
\text { bronchitis or cough, } \\
\text { asthma in their child }\end{array}$ & $\begin{array}{c}\text { No significant association } \\
\text { between any reported } \\
\text { parental pesticide use during } \\
\text { pregnancy and the } \\
\text { development of persistent } \\
\text { cough, bronchitis and asthma } \\
\text { among the offspring of farm } \\
\text { families }\end{array}$ \\
\hline GLYNN [35] & $\begin{array}{l}\text { Uppsala, } \\
\text { Sweden }\end{array}$ & Prospective cohort & $\begin{array}{l}190 \text { primiparous } \\
\text { women living and } \\
\text { seeking prenatal } \\
\text { care in Uppsala, } \\
\text { age: } 3 \text { months }\end{array}$ & DDE & $\begin{array}{l}\text { Maternal serum (32-34th week of } \\
\text { pregnancy): pp'DDE (mean } 88 \mathrm{ng} \cdot \mathrm{g}^{-1} \text { ) } \\
\text { Mother's breast milk: pp'DDE } \\
\text { (mean } 311 \mathrm{ng} \cdot \mathrm{g}^{-1} \text { ) }\end{array}$ & $\begin{array}{l}\text { Face-to-face } \\
\text { questionnaire report of } \\
\text { respiratory symptoms in } \\
\text { infant, or doctor diagnosis } \\
\text { of respiratory infection }\end{array}$ & $\begin{array}{c}\text { No association between } \\
\text { prenatal serum levels DDE } \\
\text { and respiratory infections in } \\
\text { the infants }\end{array}$ \\
\hline Liv [36] & USA & $\begin{array}{l}\text { Birth cohort of the } \\
\text { Columbia Center for } \\
\text { Children's } \\
\text { Environmental } \\
\text { Health (CCCEH) }\end{array}$ & $\begin{array}{l}224 \text { children, age: } \\
5-6 \text { years, } 50.0 \% \\
\text { male }\end{array}$ & $\begin{array}{l}\text { Pesticides: } \\
\text { permethrins and } \\
\text { PBO (a synergist for } \\
\text { residential pyrethroid } \\
\text { insecticides) }\end{array}$ & $\begin{array}{c}\text { Residential air samples in the } \\
\text { third trimester of pregnancy: PBO } \\
\text { (mean } 1.1 \mathrm{ng} \cdot \mathrm{m}^{-3} \text { ); Cis-permethrin } \\
\text { (not calculated); Trans-permethrin } \\
\text { (mean } 0.8 \mathrm{ng} \cdot \mathrm{m}^{-3} \text { ) } \\
\text { Residential air samples at } 5-6 \text { years: } \\
\text { PBO (LODs } 0.06 \mathrm{ng} \cdot \mathrm{m}^{-3} \text { ); } \\
\text { Cis-permethrin (LOD } 0.1 \mathrm{ng} \cdot \mathrm{m}^{-3} \text { ) } \\
\text { Trans-permethrin (LOD } 0.2 \mathrm{ng} \cdot \mathrm{m}^{-3} \text { ) }\end{array}$ & $\begin{array}{c}\text { Face-to-face } \\
\text { questionnaire report of } \\
\text { doctor-diagnosed of } \\
\text { asthma based on ISAAC } \\
\text { questionnaire }\end{array}$ & $\begin{array}{c}\text { Significant association } \\
\text { between prenatal exposure to } \\
\text { PBO and non-infectious } \\
\text { cough in children aged } \\
\text { 5-6 years (OR 1.27, 95\% Cl } \\
1.09-1.48 \text { ) }\end{array}$ \\
\hline
\end{tabular}


mothers on Menorca during antenatal care over a period of 12 months in 1997-1998, with a follow-up of 405 children after birth until the age of 6 years. The authors found that the concentration of dichlorodiphenyldichloroethylene (DDE), a metabolite of dichlorodiphenyl trichloroethane (DDT), in the cord blood at birth was associated with an increased risk of wheezing at 4 years of age (relative risk 2.36, $95 \%$ CI 1.19-4.69) for the highest quartile $\left(>1.90 \mathrm{ng} \cdot \mathrm{mL}^{-1}\right)$. In 2006, in a new study, the same authors, who had performed assays on cord blood at birth on 402 children, confirmed the association between DDE concentrations in cord blood and 1) the risk of asthma at 6 years of age (OR 1.18, 95\% CI 1.01-1.39); and 2) a moderate, but not significant, increase in wheezing (OR 1.13, 95\% CI 0.98-1.30) at 4 years after adjusting on duration of breastfeeding [31]. The same team also measured maternal serum concentrations of DDE, polychlorinated biphenyls (PCBs) and hexachlorobenzene (HCB) during pregnancy in a cohort in Catalonia (Infancia y Medico Ambiente) to investigate the risk of lower respiratory tract infection and wheezing in infants. The first analysis in this cohort, conducted on 520 mother-child pairs from the city of Sabadell, showed an association between maternal DDE levels $>83 \mathrm{ng} \cdot \mathrm{L}^{-1}$ and recurrent infections of the lower respiratory tract of children (relative risk 2.40, 95\% CI 1.19-4.83), a result observed at the age of 6 months (relative risk 1.68, 95\% CI 0.06-2.66) and also 14 months (relative risk 1.52, 95\% CI 1.05-2.21) [32]. The second analysis in this cohort was carried out on 1455 mother-child pairs and focused on the risk of lower respiratory tract infection and the occurrence of wheezing in infants aged 12-14 months [33]. Maternal sera DDE concentrations during the first trimester of pregnancy were associated with a risk of lower respiratory tract infection (relative risk 1.11, 95\% CI 1.00-1.22), even after an adjustment on other substances such as PCBs and HCB, which was statistically significant for the third quartile (relative risk 1.33 , 95\% CI 1.08-1.62) only.

The Ontario Farm Family Health Study explored respiratory health effects among 3405 children (from 1 to $>12$ years-old) of farmers having used pesticides on the six largest crops of this state. No significant association was observed between exposure to fungicides, herbicides and insecticides during pregnancy and persistent cough or bronchitis (OR 1.21, 95\% CI 0.77-1.90, $\mathrm{n}=104$ ), or asthma (OR 1.00, 95\% CI 0.71$1.40, \mathrm{n}=174)$ in children [34].

A Swedish birth cohort included 190 pregnant women and their babies up to the age of 3 months from 1996 to 1999. Prenatal exposure was estimated from maternal serum concentrations of PCBs and DDE during the first trimester of pregnancy and post-natal exposure from concentrations in mother's milk 3 weeks after birth. Prenatal exposure to DDE was inversely associated with eosinophil counts and the infection odds ratios were highest among infants with the lowest post-natal DDE exposure. However, PCBs and DDE concentrations were highly correlated, preventing identification of the most important contributor to the immune system modulations observed [35].

Finally, a cohort study was performed on 224 children of non-smoking African-American and Dominican mothers living in northern Manhattan and the South Bronx (NY, USA). The authors measured piperonyl butoxide (PBO) (a pyrethroid insecticide synergist used as a family tracer) and cis- and trans-permethrin (a pyrethroid insecticide) collected through individual air samplers worn by women during the last trimester of their pregnancy. The study took place from March 1998 to April 2006. Pesticide measurements were also conducted during two consecutive weeks in the homes of children participants aged 5-6 years between October 2005 and May 2011. This study found an association between prenatal exposure to PBO and non-infectious cough in children aged 5-6 years (OR 1.27, 95\% CI 1.09-1.48, $\mathrm{n}=217$ ), but not exposure to PBO measured at 5-6 years of age. There was no significant association with cis-and trans-permethrin in the air and cough measured prenatally or at the age of 5-6 years [36].

\section{Post-natal exposure}

Studies of post-natal pesticide exposure are summarised in table 2.

In Germany, a cross-sectional study was conducted among 343 children from Hamburg, aged 7-10 years, to analyse the link between post-natal exposure to organochlorine insecticides, particularly DDE, and the existence of asthma. The prevalence of respiratory and ear, nose and throat infections in children did not appear to be associated with exposure to organochlorines in general. However, exposure to DDE (DDE blood levels $\geqslant 0.3 \mathrm{mg} \cdot \mathrm{L}^{-1}$ ) was significantly associated with asthma (OR 3.71, 95\% CI 1.10-12.56, $\mathrm{n}=170$ ) [37]. The same author also set up a cohort of 338 schoolchildren aged 7-10 years old in Southern Hesse with study inclusion in 1994-1995 and a prospective follow-up of children in 1996-1997 [38]. No link between exposure to DDE and asthma diagnosed by a physician was found.

In Lebanon, a cross-sectional study conducted in 3291 Lebanese schoolchildren aged 5-16 years showed that different types of pesticide exposure among the parents (residential, domestic and para-occupational) were associated with a risk of respiratory diseases (OR 1.82, 95\% CI 1.40-2.37) in children. The highest risks were observed for asthma and para-occupational exposure (OR 2.98, 95\% CI 1.58-5.56), and for 
TABLE 2 Effects of pesticide exposure in children on respiratory health: post-natal exposure

\begin{tabular}{|c|c|c|c|c|c|c|c|}
\hline \multirow{2}{*}{$\begin{array}{l}\text { First author } \\
\text { [ref.] }\end{array}$} & \multirow[t]{2}{*}{ Location } & \multirow[t]{2}{*}{ Study design } & \multicolumn{4}{|c|}{ Summary of method } & \multirow[t]{2}{*}{ Results } \\
\hline & & & $\begin{array}{c}\text { Population } \\
\text { characteristics }\end{array}$ & $\begin{array}{l}\text { Pesticides of } \\
\text { interest }\end{array}$ & Exposure assessment & Health outcomes & \\
\hline Karmaus [37] & Germany & Cross-sectional & $\begin{array}{l}343 \text { second-grade } \\
\text { school children in } \\
\text { Hamburg, age: } \\
7-10 \text { years }\end{array}$ & $\mathrm{DDE}, \mathrm{HCH}$ & $\begin{array}{c}\text { Children's blood } \\
\text { (at } 7-10 \text { years): DDE (mean } \\
0.32 \mu \mathrm{g} \cdot \mathrm{L}^{-1} \text { ); HCB (mean } \\
0.22 \mu \mathrm{g} \cdot \mathrm{L}^{-1} \text { ) }\end{array}$ & $\begin{array}{l}\text { Parental self-report of } \\
\text { doctor-diagnosed asthma } \\
\text { (from ISAAC questionnaire) }\end{array}$ & $\begin{array}{l}\text { Exposure to DDE significantly } \\
\text { associated with doctor-diagnosed } \\
\text { asthma (OR } 3.71,95 \% \mathrm{Cl} 1.10-12.56 \text { ) }\end{array}$ \\
\hline Karmaus [38] & Germany & Cross-sectional & $\begin{array}{l}338 \text { second-grade } \\
\text { school children in } \\
\text { South Hesse, } \\
\text { age: } 7-10 \text { years }\end{array}$ & $\mathrm{DDE}, \mathrm{HCH}$ & $\begin{array}{l}\text { Children's blood } \\
\text { lat } 7-8 \text { years): DDE } \\
\text { (mean } 0.29 \mu \mathrm{g} \cdot \mathrm{L}^{-1} \text { ) }\end{array}$ & $\begin{array}{l}\text { Parental self-report of } \\
\text { doctor-diagnosed asthma } \\
\text { (ISAAC questionnaire) }\end{array}$ & $\begin{array}{c}\text { No association between DDE and } \\
\text { child's respiratory and allergic } \\
\text { symptoms }\end{array}$ \\
\hline Salameh [39] & Lebanon & Cross-sectional & $\begin{array}{l}3291 \text { children in public } \\
\text { school, } \\
\text { age: } 5-16 \text { years }\end{array}$ & Not specified & $\begin{array}{l}\text { Four questions on pesticides } \\
\text { exposure: households } \\
\text { (at work, at home or garden } \\
\text { treatment) and children (living } \\
\text { in a heavily treated region, } \\
\text { living in the proximity of a } \\
\text { heavily treated field) } \\
\text { No pesticides measured }\end{array}$ & $\begin{array}{l}\text { Parental self-report of } \\
\text { doctor-diagnosed of asthma } \\
\text { from ATS questionnaire }\end{array}$ & $\begin{array}{l}\text { Any type of exposure significantly } \\
\text { associated with respiratory disease } \\
\text { (OR } 1.71,95 \% \mathrm{Cl} 1.20-2.43 \text { ) } \\
\text { Para-occupational exposure } \\
\text { associated with risk of asthma } \\
\text { (OR } 4.61,95 \% \mathrm{Cl} 2.06-10.29 \text { ) } \\
\text { Residential exposure } \\
\text { associated with wheezing } \\
\text { (OR } 2.73,95 \% \mathrm{Cl} 1.85-4.05 \text { ) }\end{array}$ \\
\hline Salam [40] & USA & $\begin{array}{l}\text { Case-control of } \\
\text { Children's Health Study } \\
\text { (CHS) }\end{array}$ & $\begin{array}{l}691 \text { children from } \\
\text { public school, } \\
\text { including } 279 \text { cases } \\
\text { and } 412 \text { controls }\end{array}$ & Not specified & $\begin{array}{l}\text { Questions on children's } \\
\text { herbicides and pesticides } \\
\text { exposure: farm crops or dust } \\
\text { No pesticides measured }\end{array}$ & $\begin{array}{l}\text { Telephone questionnaire } \\
\text { self-report of asthma at } \\
5 \text { years of age }\end{array}$ & $\begin{array}{l}\text { Higher risk of asthma at } 5 \text { years of } \\
\text { age in children exposed to herbicides } \\
\text { (OR } 4.58,95 \% \mathrm{Cl} 1.58-5.56 \text { ) and } \\
\text { pesticide (OR } 2.39,95 \% \mathrm{Cl} 1.17-4.89 \text { ) } \\
\text { in the first year of life }\end{array}$ \\
\hline Duramad [41] & USA & $\begin{array}{l}\text { Birth cohort of the } \\
\text { Center for the Health } \\
\text { Assessment of Mothers } \\
\text { and Children of Salinas }\end{array}$ & $\begin{array}{l}412 \text { mother-infant } \\
\text { pairs, age: } 2 \text { years }\end{array}$ & $\begin{array}{l}\text { Organophosphate } \\
\text { and pyrethroid } \\
\text { insecticides }\end{array}$ & $\begin{array}{l}\text { Home inspection during } \\
\text { pregnancy, shortly after } \\
\text { delivery and at } 6,12 \text {, and } \\
24 \text { months } \\
\text { Information collected on } \\
\text { agricultural work of mother } \\
\text { and father and other } \\
\text { household members, and } \\
\text { home pesticide use } \\
\text { No pesticides measured }\end{array}$ & $\begin{array}{l}\text { Face-to-face questionnaire } \\
\text { of asthma symptoms } \\
\text { Medical records from } \\
24 \text { months: diagnosis of } \\
\text { asthma, eczema, bronchitis, } \\
\text { bronchiolitis, or pneumonia }\end{array}$ & $\begin{array}{l}\text { Significantly higher Th2 cytokine } \\
\text { level (biomarker of allergic asthma) } \\
\text { in children of women who worked } \\
\text { in the fields ( } p=0.001 \text { ) } \\
\text { Maternal agricultural work associated } \\
\text { with higher Th2 cytokine levels in } \\
\text { children ( } p=0.04 \text { ) }\end{array}$ \\
\hline TAGiYEVA [42] & UK & Prospective cohort & $\begin{array}{l}13971 \text { children } \\
\text { surviving to } 1 \text { year, } \\
\text { age: } 7.5 \text { years } \\
\text { (91 months) }\end{array}$ & $\begin{array}{l}\text { Biocides and } \\
\text { fungicides }\end{array}$ & $\begin{array}{l}\text { Children's exposure } \\
\text { determined by parental } \\
\text { job-exposure matrix } \\
\text { No pesticides measured }\end{array}$ & $\begin{array}{l}\text { Parental report of children's } \\
\text { wheeze at age } 6,18,30,42, \\
54,69 \text { and } 81 \text { months } \\
\text { At } 91 \text { months: question on } \\
\text { ever doctor-diagnosed } \\
\text { asthma in children }\end{array}$ & $\begin{array}{c}\text { Maternal post-natal exposure } \\
\text { associated with: wheeze at } 81 \text { months } \\
\text { of age (OR 1.22, } 95 \% \mathrm{Cl} 1.02-2.05 \text { ); } \\
\text { doctor-diagnosed asthma at } \\
91 \text { months (OR 1.47, 95\% Cl 1.14-1.88) }\end{array}$ \\
\hline$X \cup[43]$ & USA & $\begin{array}{l}\text { Cross-sectional of } \\
\text { National Health and } \\
\text { Nutrition Examination } \\
\text { Survey }\end{array}$ & $\begin{array}{c}14065 \text { children, age: } \\
0-17 \text { years }\end{array}$ & Not specified & $\begin{array}{l}\text { Questions on children's } \\
\text { pesticides exposure at home } \\
\text { and/or yard } \\
\text { No pesticides measured }\end{array}$ & $\begin{array}{l}\text { Parental face-to-face } \\
\text { questionnaire report of } \\
\text { doctor-diagnosed asthma, } \\
\text { and information about acute } \\
\text { respiratory problems } \\
\text { (wheezing, dry cough and } \\
\text { chronic symptoms) reported } \\
\text { by parents }\end{array}$ & $\begin{array}{l}\text { Pesticide use in the kitchen } \\
\text { or dining room and wheezing } \\
\text { (OR } 1.39,95 \% \mathrm{Cl} 1.08-1.78 \text { ) and dry } \\
\text { cough (OR } 2.38,95 \% \mathrm{Cl} 1.40-4.06 \text { ) }\end{array}$ \\
\hline
\end{tabular}

DDE: dichlorodiphenyldichloroethylene; $\mathrm{HCH}$ : hexachlorocyclohexane; HCB: hexachlorobenzene; ISAAC: International Study of Asthma and Allergies in Childhood; ATS: American Thoracic Society; Th2: T-helper cell type 2. 
wheezing and residential exposure (OR 2.53, 95\% CI 1.93-3.33). Exposure was assessed through a questionnaire on family conditions of exposure [39].

In Southern California, a case-control study on early life environmental risk factors for asthma was performed on a sample of 691 subjects selected from the Children's Health Study cohort recruited from public schools (fourth, seventh and 10th grades). Pesticide exposure was assessed by a phone questionnaire with the children's mothers about agricultural and domestic use of pesticides. An analysis of 279 children with asthma and 412 children without asthma showed that asthma diagnosed before 5 years of age was associated with exposure to herbicides (OR 4.58, 95\% CI 1.36-15.43) and to other pesticides (OR 2.39, 95\% CI 1.17-4.89) both at home and outdoors in the first year of life [40].

In the Centre for the Health Assessment of Mothers and Children of Salinas cohort in California, the link between exposures related to the agricultural occupation of mothers and T-helper cell (Th)1/Th2 profiles of CD4 lymphocytes (Th2 is a marker of asthma and allergy) was studied in 239 children aged 24 months and living on a farm. The Th2 profile of children was more prevalent when the mother worked in the fields or in the presence of at least one farm worker in the household ( 0.9 versus $0.6 \%$ and 0.8 versus $0.6 \%$ Th2 CD4 lymphocytes, respectively) [41].

Starting in 1991, the Avon Longitudinal Study of Parents and Children cohort of newborns recruited 11193 UK mothers during their pregnancy and followed 4631 of them after birth, as well as their children up to the age of 7.5 years. Parental occupational exposures were estimated by using a job-exposure matrix. High levels of maternal occupational exposure to biocides and fungicides after birth increased the likelihood of wheezing (OR 1.22, 95\% CI 1.02-2.05) and childhood asthma at 7.5 years (OR 1.47, 95\% CI 1.14-1.88). This exposure, combined with an exposure to latex, increased the likelihood of wheezing during childhood (OR 1.22, 95\% CI 1.03-1.43) and asthma at 7.5 years (OR 1 47, 95\% CI 1.14-1.47) [42].

The National Health and Nutrition Examination Survey (1999-2004) in the USA is a repeated study measuring the exposure to many substances and making health examinations in a panel of the US population. In this survey, the link between respiratory symptoms and domestic use of pesticides was studied in 14065 children under 18 years of age. General pesticide use was not associated with respiratory symptoms, but use of such substances in the kitchen and the dining room was associated with wheezing (OR 1.39, 95\% CI 1.08-1.78) and dry cough (OR 2.38, 95\% CI 1.40-4.06) [43].

Most of these studies showed that children, and moreover those living in agricultural areas may be exposed to pesticides introduced into their homes by family members exposed to pesticides because of their job or by residential proximity to fields and by domestic uses.

In summary, a significant relationship between environmental exposure and respiratory symptoms (asthma, wheezing or cough) in children was found in 11 studies (six for prenatal exposure and five for post-natal exposure). For three studies, no relationship was found (three for prenatal exposure and one for post-natal exposure).

\section{Studies in adults}

Few studies have been conducted regarding environmental pesticide exposure of adults (table 3 ). In the USA, a cross-sectional study was conducted among 117 employees of a health centre, aged 21-68 years and including 94\% women. These subjects were exposed between 1969 and 1981 to a stock of pesticides for mosquito control (Malathion and DDT), stored and handled in the building. The duration of employment (at least 3 years) (OR 4.3, 95\% CI 1.7-1.0) was significantly associated with bronchitis and sinusitis reported by the subjects. However, the concentrations of these pesticides measured in serum and urine were not associated with any symptom [44].

Three studies focused on the respiratory symptoms in inhabitants of pesticide application areas in the USA: one study in which application was aerial [45], one in which a spreading truck was used [46] and one in which a joint helicopter-truck application was performed [47]. The first study was conducted in California among 39 residents living near farms where paraquat had been applied by helicopter for 2 weeks and in 172 control subjects living in three urban areas far from application areas. During the application period, the authors found a significant increase in ten symptoms among residents, including coughing frequency (relative risk 2.60, $\mathrm{p}<0.001$ ) and wheezing (relative risk 3.04, $\mathrm{p}<0.01$ ). These symptoms and the total number of symptoms were significantly associated with the fact of having noticed an unusual smell during the study period $(\mathrm{p}<0.05)[45]$.

The second study involved a wide mosquito control campaign conducted in five areas of the city of New York. This retrospective study focused on all consultations for asthma in the emergency departments of public hospitals from October 1999 to November 2000. The analysis focused on 62827 visits over a period of 427 days. The number of visits for asthma was similar during the 3 days before and after 
TABLE 3 Effects on respiratory health and exposure to pesticides in the general population

\begin{tabular}{|c|c|c|c|c|c|c|c|}
\hline \multirow{2}{*}{$\begin{array}{l}\text { First author } \\
\text { [ref.] }\end{array}$} & \multirow[t]{2}{*}{ Location } & \multirow[t]{2}{*}{ Study design } & \multicolumn{4}{|c|}{ Summary of method } & \multirow[t]{2}{*}{ Results } \\
\hline & & & $\begin{array}{l}\text { Population } \\
\text { characteristics }\end{array}$ & Pesticides of interest & Exposure assessment & Health outcomes & \\
\hline BALLUZ [44] & USA & Cross-sectional & $\begin{array}{l}117 \text { employees of a } \\
\text { health centre in } \\
\text { Georgia, } 94 \% \\
\text { women, aged: } \\
21-68 \text { years }\end{array}$ & $\begin{array}{c}\text { Malathion, } \\
\text { Organochlorines including } \\
\text { DDT: stored, handled and } \\
\text { used in the fight against } \\
\text { mosquitoes }\end{array}$ & $\begin{array}{l}\text { Environmental sampling of } \\
\text { pesticides in the building: } \\
\text { Malathion }\left(110 \mu \mathrm{g} \cdot \mathrm{g}^{-1}\right) \text {; } \\
\left.\text { DDT (24 } \mathrm{\mu g} \cdot \mathrm{g}^{-1}\right) \\
\text { Measures of } 17 \mathrm{chlorinated} \\
\text { pesticides in serum and urine } \\
\text { of employees (concentrations } \\
\text { below } 95 \% \text { limit for the } \\
\text { reference range for the US } \\
\text { population) }\end{array}$ & $\begin{array}{l}\text { Self-reported occurrence } \\
\text { and severity of respiratory } \\
\text { illnesses and symptoms }\end{array}$ & $\begin{array}{l}\text { Duration of employment lat least } \\
3 \text { years) significantly associated } \\
\text { with bronchitis (OR 4.3, } \\
95 \% \mathrm{Cl} 1.7-11.0 \text { ) and sinusitis } \\
\text { (OR } 3.7,95 \% \mathrm{Cl} 1.5-8.7 \text { ) } \\
\text { No association between health } \\
\text { complaint and pesticide levels in } \\
\text { serum and urine }\end{array}$ \\
\hline Ames [45] & USA & $\begin{array}{l}\text { Retrospective } \\
\text { study }\end{array}$ & $\begin{array}{l}39 \text { subjects who } \\
\text { were residents living } \\
\text { near farms where } \\
\text { paraquat was } \\
\text { applied and } 172 \\
\text { controls living in } \\
\text { areas remote from } \\
\text { spraying }\end{array}$ & Paraquat & $\begin{array}{l}\text { Living near farms where } \\
\text { paraquat was applied lan area } \\
\text { of } \sim 0.5 \text { miles) } \\
\text { Self-reported perception of } \\
\text { odour during the } 2 \text { weeks of } \\
\text { study period }\end{array}$ & $\begin{array}{l}\text { Self-reported symptoms } \\
\text { during the } 2 \text {-week study } \\
\text { period }\end{array}$ & $\begin{array}{l}\text { Significant increased risk for cough } \\
\text { (RR } 2.60 ; p<0.001 \text { ) and wheezing } \\
\text { (RR } 3.04 ; p<0.01 \text {, Chi-squared) in } \\
\text { the paraquat-exposed group }\end{array}$ \\
\hline KARPATI [46] & USA & $\begin{array}{l}\text { Retrospective } \\
\text { study after a } \\
\text { mosquito } \\
\text { eradication } \\
\text { programme }\end{array}$ & $\begin{array}{l}62827 \text { visits for } \\
\text { asthma in the ED of } \\
\text { hospitals in } \\
\text { New York, study } \\
\text { period, mean age: } \\
34 \text { years }\end{array}$ & $\begin{array}{l}\text { Pyrethroid insecticides } \\
\text { sprayed in New York City } \\
\text { during July-September } \\
2000 \text { to control mosquito } \\
\text { vectors of West Nile virus }\end{array}$ & None & $\begin{array}{l}\text { Data obtained from the } \\
\text { New York City Health and } \\
\text { Hospitals Corporation for } \\
\text { ED visits for asthma during } \\
\text { pesticide spraying period }\end{array}$ & $\begin{array}{l}\text { No significant association } \\
\text { between pesticide spraying days } \\
\text { and daily rates of asthma visits } \\
\text { (RR } 0.92,95 \% \mathrm{Cl} 0.80-1.07 \text { ] }\end{array}$ \\
\hline 0'SulLivan [47] & USA & $\begin{array}{l}\text { Retrospective } \\
\text { study after a } \\
\text { mosquito } \\
\text { eradication } \\
\text { programme }\end{array}$ & $\begin{array}{l}1318 \text { patients with a } \\
\text { diagnosis of asthma } \\
\text { in the ED of Lincoln } \\
\text { hospital (South } \\
\text { Bronx, NY) during } \\
\text { 1997, } 1998 \text { and } 1999\end{array}$ & $\begin{array}{c}\text { Malathion } \\
\text { (organophosphate } \\
\text { insecticide) and } \\
\text { andresmethrin ( pyrethroid } \\
\text { insecticide) sprayed } \\
\text { during the mosquito } \\
\text { eradication programme in } \\
\text { South Bronx in September } \\
1999\end{array}$ & None & $\begin{array}{l}\text { Adult and paediatric asthma } \\
\text { ED admissions during the } \\
4 \text { days (September 1999) of } \\
\text { the mosquito eradication } \\
\text { programme }\end{array}$ & $\begin{array}{c}\text { No significant differences in } \\
\text { patient ED asthma admissions } \\
\text { between spraying and non-spraying } \\
\text { days in September } 1999 \\
\text { No significant difference between } \\
\text { the number of ED asthma } \\
\text { admissions in September } 1999 \\
\text { compared with } 1997 \text { and } 1998\end{array}$ \\
\hline ZHANG [48] & China & Cross-sectional & $\begin{array}{c}22528 \text { rural adults, } \\
48.7 \% \text { men, } \\
\text { age } \geqslant 15 \text { years }\end{array}$ & Insecticides & $\begin{array}{l}\text { Face-to-face questionnaire to } \\
\text { obtain information on regular } \\
\text { occupational and } \\
\text { environmental exposure to } \\
\text { chemicals (insecticides) }\end{array}$ & $\begin{array}{l}\text { Face-to-face questionnaire } \\
\text { (IUATLD questionnaire) } \\
\text { about respiratory symptoms } \\
\text { during the past } 12 \text { months }\end{array}$ & $\begin{array}{c}\text { Exposure to insecticides associated } \\
\text { with higher prevalence of chronic } \\
\text { cough (OR } 2.2,95 \% \mathrm{Cl} 1.4-3.3 \text { ), } \\
\text { asthma attack (OR } 1.9,95 \% \\
\mathrm{CI} 1.3-2.9 \text { ) and wheeze } \\
\text { (OR } 1.8,95 \% \mathrm{Cl} 1.2-2.6 \text { ) }\end{array}$ \\
\hline LEVAN [49] & Singapore & $\begin{array}{l}\text { Prospctive cohort } \\
\text { (Singapore } \\
\text { Chinese Health } \\
\text { Study, SCHS) }\end{array}$ & $\begin{array}{l}52325 \text { subjects, } \\
42.6 \% \text { men, } \\
\text { age: } 45-75 \text { years }\end{array}$ & $\begin{array}{l}\text { Vapour exposure including } \\
\text { pesticides }\end{array}$ & None & $\begin{array}{l}\text { Follow-up phone } \\
\text { questionnaire based on } \\
\text { ATS-DLD: respiratory } \\
\text { symptoms, self-report of } \\
\text { physician-diagnosed } \\
\text { adult-onset asthma and } \\
\text { respiratory outcomes in } \\
\text { general }\end{array}$ & $\begin{array}{l}\text { Occupational pesticide exposure } \\
\text { associated with adult-onset } \\
\text { asthma (OR 1.69, 95\% Cl 1.13-2.52) }\end{array}$ \\
\hline
\end{tabular}

DDT: dichlorodiphenyl trichloroethane; RR: relative risk; ED: emergency department; IUATLD: International Union Against Tuberculosis and Lung Disease; ATS-DLD: American Thoracic Society Division of Lung Disease. 
application ( 510 visits in the 3 days before versus 501 visits in the 3 days after, $\mathrm{p}=0.78$ ) and no link was found between exposure and symptoms of asthma (relative risk 0.92, 95\% CI 0.80-1.07) [46].

The last study, also carried out in New York, examined the link between the application of insecticides in a neighbourhood (South Bronx) by helicopter (Malathion) and trucks (Resmethrin) in September 1999 and emergency department visits at the local hospital over the same period. No significant difference between admissions for asthma (1318 patients) over the spreading period was observed compared with the two previous years [47].

In China, a cross-sectional study was conducted among 22528 adults aged 15 years or over of both sexes (49\% men) living in 30 villages of two rural districts, to determine the link between environmental exposure to insecticides and fertilisers and respiratory symptoms. Regular exposure to insecticides was significantly associated with wheezing (OR 1.8, 95\% CI 1.2-2.6), chronic cough (OR 2.2, 95\% CI 1.4-3.3) and asthma attacks over the past 12 months (OR 1.9, 95\% CI 1.3-2.9). Exposure to fertilisers was significantly associated with a risk of wheezing (OR 1.4,95\% CI 1.1-1.8) as well as a slight increase in chronic cough (OR 1.3, 95\% CI 0.9-1.8) and asthma attacks over the past 12 months (OR 1.3, 95\% CI 0.9-1.7) [48].

The Singapore Chinese Health Study followed 52325 subjects aged 45-74 years, recruited among permanent residents or citizens of Singapore over the period 1993-1998, and documented their occupational exposure to various chemicals (dyes, paints and pesticides). This study showed that occupational exposure to pesticides was associated with the onset of asthma in adulthood (OR 1.69, 95\% CI 1.13-2.52] [49].

Thus, the inconsistent results of these few studies do not allow us to conclude to a link between environmental exposure to pesticides and respiratory symptoms or diseases in adults.

\section{Discussion}

The responsibility of environmental factors in the development of chronic respiratory diseases is now established. Pesticides are a well-documented risk factor for professionals who use them. However, by analogy with other respiratory risk factors such as air pollution, some researchers have come to ask whether pesticides could also be involved in diseases and respiratory symptoms in populations living near areas where these products were used, and in the general population exposed via domestic pesticide use. Thus, the objective of this work was to review the literature on the potential respiratory risks of environmental exposure to pesticides. The PubMed database search identified 20 different studies, including 14 on children, about non-occupational exposure. Thus, there are far fewer studies than those carried out in the workplace, with much more mixed and sparse results.

Health data collected in these studies were mainly based on the use of standardised questionnaires that parents answered. The International Study of Asthma and Allergies in Childhood questionnaire was used in five studies; while the questionnaire of the American Thoracic Society was used in one study on children and two studies on adults. Other authors had their own standardised questionnaire with questions such as: has a doctor ever diagnosed a respiratory health problem in your child? In the studies reported here, exposure was measured by assays of pesticide metabolites in blood and/or breast milk in eight of the studies carried out among children; environmental measurements of pesticides were conducted via individual air samplers in a single study [36]. In all other studies, pesticide exposure was assessed either through answers to the questionnaire on exposure, or the occupation of the parents, or the area of residence.

Among the 14 studies on children, only three showed no link with maternal exposure to pesticides post-partum or during pregnancy $[34,35,38]$. In utero exposures to DDE have often been associated with asthma in young children (3-6 months after birth) [30-33] and with wheezing [33]. SunYer et al. [31] concluded that prenatal exposure to DDE might contribute to the development of childhood asthma, but it did not alter the protective effect of breastfeeding from asthma. Karmaus and colleagues reached the same conclusions in children aged 7-10 years [37, 38]. However, some authors [34, 35] did not find strong associations between exposure to organochlorines during pregnancy and respiratory symptoms in infants after birth (persistent cough, bronchitis or asthma). Moreover, the results of some studies have indicated that early exposure to pesticides up to the age of 4 years is the most relevant time window of exposure [30, 31]. It was also shown that contact of the children in the first year of life with a mother who was herself in contact with pesticides in the case of occupational and/or residential exposure was likely to increase the likelihood of wheezing and childhood asthma [39, 42], non-infectious cough in children aged 5-6 years [36], and wheezing in children under 18 years of age [43].

A recent review was published, by GASCON et al. [50], on the effects of persistent organic pollutants (DDE, PCBs, HCB, hexachlorocyclohexanes and other persistent organic pollutants) on the developing respiratory and immune systems. The authors noted that children living in agricultural areas may be exposed to higher 
levels of pesticides than other children. They conclude from their review that persistent organic pollutant compounds could adversely influence immune and respiratory system development, nevertheless they considered that we need further studies to achieve a better understanding of the underlying mechanisms [50].

The results of the fewer studies on environmental exposure among adults are much less conclusive. Only three authors found a link between environmental exposure to pesticides and respiratory symptoms, but this association was not very significant $[45,48,49]$. A multivariate analysis showed that the symptoms reported by the subjects were significantly associated with the perception of certain odours or periods of employment under conditions of environmental exposure, despite the fact that biological monitoring had not provided evidence of higher exposure to malathion, DDT or other chlorinated compounds [44]. In both studies carried out on New Yorkers, the authors did not find any link between the frequency of respiratory symptoms or asthma attacks and applications of pesticides $[46,47]$. However, it is important to note that information had been given before the campaign to the residents of affected areas about the dates of passage of trucks and helicopters, as well as recommendations to stay indoors and keep windows closed. It is possible, therefore, that residents suffering from asthma or other respiratory diseases took special precautions (e.g. staying inside and taking a prophylactic treatment) to avoid exposure or the potential effects of applied pesticides.

The lower degree of certainty of epidemiological studies on environmental exposure to pesticides compared with those on occupational exposure can be explained by different reasons. A key question arises about the potential effect of environmental human exposure to pesticides: do pesticide exposure levels experienced by people living near treated fields compare with those observed in occupational settings? This is a complex issue, because in surveys on the respiratory health of workers exposed to pesticides environmental or personal measurements have been performed, whereas the majority of studies dealing with non-occupational pesticide exposure have used biological monitoring, either in breast milk, the mother's or child's blood, or in cord blood. Therefore, it is difficult to compare pesticide levels between occupational studies and environmental studies. However, our experience of pesticide exposure studies in various settings (data non published) enables us to assume that pesticide residues in diet, water and environment lead to general population exposures at levels 100 to more than 10000 lower than levels of occupational exposure, measured during handling of pesticides but also during re-entry and harvest (i.e. from 0.01 to $1000 \mu \mathrm{g}$ per day from non-occupational sources and from 1 to $10000 \mu \mathrm{g}$ per day in occupational settings).

However, a number of methodological issues remain in the epidemiological studies reviewed here. As we have seen, the majority of these studies were cross-sectional, leading to potential underestimation of the impact of certain exposures, because most affected people may have changed their exposure following the appearance of respiratory symptoms or the diagnosis of a respiratory disease. In addition, as pointed out by some authors themselves, cross-sectional studies do not allow determination of which characteristics of agricultural or non-agricultural lifestyle, including the physical environment, contribute to the variations in respiratory health problems. More case-control or cohort studies would be necessary to clarify the respective roles of potential contributing factors. Another potential bias lies in the identification and quantification of pesticides. In many studies on environmental exposure, the nature of the pesticides to which subjects were exposed was not specified. Furthermore, even when the precise nature of the pesticide was known, information regarding frequency, duration and/or intensity of exposure and pesticide formulation often remained scarce. Few studies have assessed direct personal exposure to pesticides by measurements, although this might not be the most accurate tool for assessing past exposures [34], and only two studies have focused on household use of pesticides or use in the garden $[36,43]$.

Future studies should use more environmental measurements and biomarkers of exposure in combination with detailed questionnaires and more precise assessment of pesticide uses around the home in agriculture or other industries. Indeed, a more accurate estimation of non-occupational pesticide exposures could help identify potential dose-response links and chemicals involved with respiratory diseases or symptoms.

It should also be noted that the size of some studies was much smaller than those of studies carried out on workers, which could have reduced their power and prevented highlighting of some associations. Finally, it is worth noting that in some studies, the identification of symptoms and diseases was based on self-reporting by subjects, which can lead to biases in information, as has also been noted in some occupational exposure studies. However, the use of validated standardised questionnaires, as they exist in respiratory epidemiology, can limit this drawback, in parallel with lung function measurements.

In conclusion, despite consistent data indicating increased risks for some respiratory diseases/symptoms with occupational and accidental exposure to pesticides, their harmfulness is still not clear in the case of environmental exposure. Further studies should be performed, with a more rigorous design and protocol. Exposed/unexposed or cohort studies should be performed, and more precise evaluations of exposure based on the most accurate possible identification of the incriminated pesticides should also be carried out. 
Research and quantification of active substances in the environment and biological matrices are interesting tools, as well as the study of exposures over long periods prior to the occurrence of any respiratory symptoms. The existence of respiratory risks associated with environmental exposure to pesticides should lead, if confirmed, to the implementation of effective interventions to improve the protection of populations.

\section{References}

1 American College of Chest Physicians. Global Reports. FIRS Report: Respiratory Diseases in the World www.chestnet.org/Guidelines-and-Resources/Health-Policy/FIRS-Report-Respiratory-Diseases-in-the-World Date last accessed: April 9, 2014.

2 Pearce N, Ait-Khaled N, Beasley R, et al. Worldwide trends in the prevalence of asthma symptoms: phase III of the International Study of Asthma and Allergies in Childhood (ISAAC). Thorax 2007; 62: 758-766.

3 Walker CL, Rudan I, Liu L, et al. Global burden of childhood pneumonia and diarrhoea. Lancet 2013; 381: 1405-1416.

4 Dalphin JC. Pathologie respiratoire en milieu agricole [Respiratory pathology in the agricultural environment]. Rev Prat 1998; 48: 1313-1318.

5 Michielsen C, Zeamari S, Leusink-Muis A, et al. The environmental pollutant hexachlorobenzene causes eosinophilic and granulomatous inflammation and in vitro airways hyperreactivity in the Brown Norway rat. Arch Toxicol 2002; 76: 236-247.

6 Bessot JC, Blaumeiser M, Kopferschmitt MC, et al. L'asthme professionnel en milieu agricole [Occupational asthma in an agricultural setting]. Rev Mal Respir 1996; 13: 205-215.

7 Crinnion WJ. Do environmental toxicants contribute to allergy and asthma? Alter Med Rev 2012; 17: 6-18.

8 Hoppin JA, Umbach DM, London SJ, et al. Animal production and wheeze in the Agricultural Health Study: interactions with atopy, asthma, and smoking. Occup Environ Med 2003; 60: e3.

9 Regulation (EU) No 528/2012 of the European Parliament and of the Council of 22 May 2012 concerning the making available on the market and use of biocidal products. Official Journal of the European Union 2012; 55: L167.

10 Bouvier G, Seta N, Vigouroux-Villard A, et al. Insecticide urinary metabolites in nonoccupationally exposed populations. J Toxicol Environ Health B Crit Rev 2005; 8: 485-512.

11 AFSSET. Exposition de la population générale aux résidus de pesticides en France. Synthèse des données d'utilisation, de contamination des milieux et d'imprégnation de la population. Plan d'action ORP 2006-2008. Maisons-Alfort, AFSSET 2010; p. 354.

12 INSERM. Pesticides: Effets sur la santé. Expertise collective. Paris, Les éditions Inserm, 2013; p. 1001.

13 Baldi I, Lebailly P, Rondeau V, et al. Levels and determinants of pesticide exposure in operators involved in treatment of vineyards: results of the PESTEXPO Study. J Expo Sci Environ Epidemiol 2012; 22: 593-600.

14 Bouvier G, Blanchard O, Momas I, et al. Pesticide exposure of non-occupationally exposed subjects compared to some occupational exposure: a French pilot study. Sci Total Environ 2006; 366: 74-91.

15 Hernández AF, Parrón T, Alarcón R. Pesticides and asthma. Curr Opin Allergy Clin Immunol 2011; 11: 90-96.

16 Proskocil BJ, Bruun DA, Lorton JK, et al. Antigen sensitization influences organophosphorus pesticide-induced airway hyperreactivity. Environ Health Perspect 2008; 116: 381-388.

17 Proskocil BJ, Bruun DA, Thompson CM, et al. Organophosphorus pesticides decrease M2 muscarinic receptor function in guinea pig airway nerves via indirect mechanisms. PLOS ONE 2010; 5: e10562.

18 Fukuyama T, Kosaka T, Tajima Y, et al. Prior exposure to organophosphorus and organochlorine pesticides increases the allergic potential of environmental chemical allergens in a local lymph node assay. Toxicol Lett 2010; 199: 347-356.

19 Eskenazi B, Bradman A, Castorina R. Exposures of children to organophosphate pesticides and their potential adverse health effects. Environ Health Perspect 1999; 107: Suppl., 409-419.

20 Sanborn MD, Cole D, Abelsohn A, et al. Identifying and managing adverse environmental health effects: 4. Pesticides. CMAJ 2002; 166: 1431-1436.

21 Steen W, Bond A, Mage D. Agricultural Health Study-Exposure Pilot Study report. Research Triangle Park, U.S. Environmental Protection Agency, 1997.

22 Moher D, Liberati A, Tetzlaff J, et al. Preferred reporting items for systematic reviews and meta-analyses: the PRISMA statement. Ann Intern Med 2009; 151: 264-269.

23 Charles LE, Burchfiel CM, Fekedulegn D, et al. Occupational exposure to pesticides, metals, and solvents: the impact on mortality rates in the Honolulu Heart Program. Work 2010; 37: 205-215.

24 O'Malley M, Barry T, Ibarra M, et al. Illnesses related to shank application of metam-sodium, Arvin, California, July 2002. J Agromedicine 2005; 10: 27-42.

25 Gomes Do Espirito Santo ME, Marrama L, Ndiaye K, et al. Investigation of deaths in an area of groundnut plantations in Casamance, South of Senegal after exposure to Carbofuran, Thiram and Benomyl. J Expo Anal Environ Epidemiol 2002; 12: 381-388.

26 Cocco P, Blair A, Congia P, et al. Long-term health effects of the occupational exposure to DDT. A preliminary report. Ann N Y Acad Sci 1997; 837: 246-256.

27 Payán-Rentería R, Garibay-Chávez G, Rangel-Ascencio R, et al. Effect of chronic pesticide exposure in farm workers of a Mexico community. Arch Environ Occup Health 2012; 67: 22-30.

28 Ohayo-Mitoko GJ, Kromhout H, Simwa JM, et al. Self reported symptoms and inhibition of acetylcholinesterase activity among Kenyan agricultural workers. Occup Environ Med 2000; 57: 195-200.

29 Awadalla NJ, Hegazy A, Elmetwally RA, et al. Occupational and environmental risk factors for idiopathic pulmonary fibrosis in Egypt: a multicenter case-control study. Int J Occup Environ Med 2012; 3: 107-116.

30 Sunyer J, Torrent M, Muñoz-Ortiz L, et al. Prenatal dichlorodiphenyldichloroethylene (DDE) and asthma in children. Environ Health Perspect 2005; 113: 1787-1790.

31 Sunyer J, Torrent M, Garcia-Esteban R, et al. Early exposure to dichlorodiphenyldichloroethylene, breastfeeding and asthma at age six. Clin Exp Allergy 2006; 36: 1236-1241.

32 Sunyer J, Garcia-Esteban R, Alvarez M, et al. DDE in mothers' blood during pregnancy and lower respiratory tract infections in their infants. Epidemiology 2010; 21: 729-735. 
33 Gascon M, Vrijheid M, Martínez D, et al. Pre-natal exposure to dichlorodiphenyldichloroethylene and infant lower respiratory tract infections and wheeze. Eur Respir J 2012; 39: 1188-1196.

34 Weselak M, Arbuckle TE, Wigle DT, et al. In utero pesticide exposure and childhood morbidity. Environ Res 2007; 103: 79-86.

35 Glynn A, Thuvander A, Aune M, et al. Immune cell counts and risks of respiratory infections among infants exposed pre- and postnatally to organochlorine compounds: a prospective study. Environ Health 2008; 7: 62.

36 Liu B, Jung KH, Horton MK, et al. Prenatal exposure to pesticide ingredient piperonyl butoxide and childhood cough in an urban cohort. Environ Int 2012; 48: 156-161.

37 Karmaus W, Kuehr J, Kruse H. Infections and atopic disorders in childhood and organochlorine exposure. Arch Environ Health 2001; 56: 485-492.

38 Karmaus W, Davis S, Chen Q, et al. Atopic manifestations, breast-feeding protection and the adverse effect of DDE. Paediatr Perinat Epidemiol 2003; 17: 212-220.

39 Salameh PR, Baldi I, Brochard P, et al. Respiratory symptoms in children and exposure to pesticides. Eur Respir J 2003; 22: 507-512.

40 Salam MT, Li YF, Langholz B, et al. Early-life environmental risk factors for asthma: findings from the Children's Health Study. Environ Health Perspect 2004; 112: 760-765.

41 Duramad P, Harley K, Lipsett M, et al. Early environmental exposures and intracellular Th1/Th2 cytokine profiles in 24-month-old children living in an agricultural area. Environ Health Perspect 2006; 114: 1916-1922.

42 Tagiyeva N, Devereux G, Semple S, et al. Parental occupation is a risk factor for childhood wheeze and asthma. Eur Respir J 2010; 35: 987-993.

$43 \mathrm{Xu} \mathrm{X}, \mathrm{Nembhard} \mathrm{WN}$, Kan $\mathrm{H}$, et al. Residential pesticide use is associated with children's respiratory symptoms. J Occup Environ Med 2012; 54: 1281-1287.

44 Balluz LS, Philen RM, Brock J, et al. Health complaints related to pesticide stored at a public health clinic. Environ Res 2000; 82: 1-6.

45 Ames RG, Howd RA, Doherty L. Community exposure to a paraquat drift. Arch Environ Health 1993; 48: 47-52.

46 Karpati AM, Perrin MC, Matte T, et al. Pesticide spraying for West Nile virus control and emergency department asthma visits in New York City, 2000. Environ Health Perspect 2004; 112: 1183-1187.

47 O'Sullivan BC, Lafleur J, Fridal K, et al. The effect of pesticide spraying on the rate and severity of ED asthma. Am J Emerg Med 2005; 23: 463-467.

48 Zhang LX, Enarson DA, He GX, et al. Occupational and environmental risk factors for respiratory symptoms in rural Beijing, China. Eur Respir J 2002; 20: 1525-1531.

49 LeVan TD, Koh WP, Lee HP, et al. Vapor, dust, and smoke exposure in relation to adult-onset asthma and chronic respiratory symptoms: the Singapore Chinese Health Study. Am J Epidemiol 2006; 163: 1118-1128.

50 Gascon M, Morales E, Sunyer J, et al. Effects of persistent organic pollutants on the developing respiratory and immune systems: a systematic review. Environ Int 2013; 52: 51-65. 